\title{
Changes in Gut Flora after Cephalexin Treatment
}

\author{
H. GAYA,* м.в., СH.в. ; P. I. ADNITT, $†$ M.D., M.R.C.P. ; P. TURNER, $\ddagger$ M.D., B.SC., M.R.C.P.
}

\begin{abstract}
Cummary: Eighteen patients with urinary tract infection were treated with cephalexin orally. Absorption was variable, between 29 and $89 \%$ of the total daily dose being excreted in the urine in 24 hours. A significant number of patients became faecal carriers of Pseudomonas aeruginosa compared with a control group who received no antibiotics. Four of the cephalexintreated patients acquired a strain of $P s$. aeruginosa known to be present in food from the hospital diet kitchen and one developed a urinary tract infection with this strain.
\end{abstract}

\section{Introduction}

Cephalexin is a new cephalosporin antibiotic which, unlike cephaloridine, is well absorbed when given orally (Gower and Dash, 1969). It has been used in the treatment of urinary tract (Levison et al., 1969) and respiratory infections (Seftel et al., 1969). Absorption has been claimed to approach $100 \%$, and it has been suggested, therefore, that this antibiotic would have little or no effect on intestinal bacterial flora (Gower and Dash, 1969). Our own experience does not entirely support these views.

\section{Patients and Methods}

Eighteen patients ( 3 men and 15 women) aged 48 to 81 with urinary tract infection were studied. All organisms were sensitive to cephalexin, a $30-\mu \mathrm{g}$. disc on the primary plate being used. Each patient received cephalexin (Eli Lilly \& Co.) 0.5 or $1 \mathrm{~g}$. four times daily for 14 days. Haemoglobin level, haematocrit value, white cell and platelet counts, serum aspartate aminotransferase, alkaline phosphatase, blood urea, and bilirubin were determined before, during, and at the end of treatment. Stool and urine specimens were taken before and during treatment and three days after treatment ended.

During the second week of treatment a 24-hour collection of urine was taken, stored at $4^{\circ} \mathrm{C}$. during collection and thereafter at $-20^{\circ} \mathrm{C}$. At the same time blood samples were taken immediately before and at intervals after the mid-morning dose of cephalexin, which was administered three hours after breakfast and one hour before lunch. Cephalexin levels were measured by a plate assay method, Sarcina lutea (N.C.I.B. 8533) being used as test organism. To avoid observer bias specimens were identified only by a code number.

\section{Results}

The serum cephalexin levels in six patients during the three hours after the mid-morning dose are given in Fig. $1 \mathrm{~A}$, and serum cephalexin levels at one hour (18 patients) and four hours (15 patients) after administration in Fig. 1 B. Details of the infecting organisms and response to treatment with cephalexin for 12 patients are given in Table I. Cephalexin concentration in 24-hour urine collections is also shown together with the percentage of the daily oral dose recovered.

The numbers of patients acquiring proteus or Pseudomonas

* Lecturer in Bacteriology, St. Bartholomew's Hospital, London, E.C.1 + Senior Registrar in Medicine, St. Bartholomew's Hospital, London, E.C.1. ‡ Reader in Clinical Pharmacology, St. Bartholomew's Hospital, London, aeruginosa in the stool following cephalexin treatment are shown in Table II. Comparison is made with 11 patients on the ward at the same time who received other antibiotics (oral ampicillin 6, oral tetracycline 2, other antibiotics 3 ) and with 16 patients who had no antibacterial therapy while in hospital. Seven out of 12 cephalexin-treated patients acquired

TABLE I.-Response to Treatment and Urinary Excretion of Cephalexin

\begin{tabular}{|c|c|c|c|c|c|c|c|c|}
\hline & $\begin{array}{l}\text { Cas } \\
\text { No. }\end{array}$ & & $\begin{array}{l}\text { Infecting } \\
\text { Organism }\end{array}$ & $\begin{array}{c}\text { Post- } \\
\text { treatment } \\
\text { Culture }\end{array}$ & $\begin{array}{c}\text { Original } \\
\text { Pathogen } \\
\text { Elimi- } \\
\text { nated }\end{array}$ & $\begin{array}{c}\text { Daily } \\
\text { Dose } \\
\text { Cepha- } \\
\text { lexin } \\
\text { (g.) }\end{array}$ & $\begin{array}{c}\text { Urine } \\
\text { Concen- } \\
\text { tration } \\
\text { (ug./ml.) }\end{array}$ & $\begin{array}{c}\% \text { of } \\
\text { Daily } \\
\text { Dose } \\
\text { Excreted }\end{array}$ \\
\hline $\begin{array}{l}1 \\
2 \\
3 \\
4\end{array}$ & $\begin{array}{l}\because \\
\because \\
\therefore\end{array}$ & : & $\begin{array}{l}\text { E. coli } \\
\text { Pr.mirabilis } \\
\text { E. coli } \\
\text { Pr. mirabilis }\end{array}$ & \begin{tabular}{l|} 
Sterile \\
Sterile \\
Sterile \\
Str. faecalis
\end{tabular} & $\begin{array}{l}+ \\
+\end{array}$ & $\begin{array}{l}4 \\
4 \\
4\end{array}$ & $\begin{array}{l}2,000 \\
4,700\end{array}$ & $\begin{array}{l}64 \\
65\end{array}$ \\
\hline $\begin{array}{r}5 \\
6 \\
7 \\
8 \\
9 \\
10 \\
11 \\
12\end{array}$ & $\begin{array}{l}. \\
\therefore \\
\therefore \\
\because \\
\therefore \\
\therefore\end{array}$ & $\begin{array}{l}. \\
\therefore \\
\therefore \\
\therefore \\
\therefore \\
\therefore\end{array}$ & $\begin{array}{l}\text { E. coli } \\
\text { Klebsiella } \\
\text { Coliform } \\
\text { E. coli } \\
\text { E. coli } \\
\text { Klebsiella } \\
\text { E. coli } \\
\text { E. coli }\end{array}$ & $\begin{array}{l}\text { Candida } \\
\text { Sterile } \\
\text { Klebsiella } \\
\text { Coliform } \\
\text { Sterile } \\
\text { Sterile } \\
\text { Sterile } \\
\text { Ps.aeruginosa } \\
\text { E. coli }\end{array}$ & $\begin{array}{l}+ \\
\pm \\
\pm \\
+ \\
+ \\
+ \\
\pm \\
-\end{array}$ & $\begin{array}{l}4 \\
4 \\
4 \\
4 \\
2 \\
2 \\
2 \\
2 \\
2 \\
2\end{array}$ & $\begin{array}{l}920 \\
760\end{array}$ & $\begin{array}{l}29 \\
45\end{array}$ \\
\hline
\end{tabular}

TABLE II.-Acquisition of Ps. aeruginosa and Proteus in Patients Treated with Cephalexin, with Other Antibiotics, or Given no Antibiotic Treatment

\begin{tabular}{|c|c|c|c|c|c|c|}
\hline \multirow{2}{*}{ Antibiotic } & & \multirow{2}{*}{$\begin{array}{c}\text { No. of } \\
\text { Patients }\end{array}$} & \multicolumn{4}{|c|}{ Acquisition } \\
\hline & & & Ps. aeruginosa & Proteus & Both & Neither \\
\hline $\begin{array}{l}\text { Cephalexin .. } \\
\text { Others } \quad . \\
\text { None }\end{array}$ & $\begin{array}{l}. \\
\cdots\end{array}$ & $\begin{array}{l}12 \\
11 \\
16\end{array}$ & $\begin{array}{l}7 \\
3 \\
1\end{array}$ & $\begin{array}{l}4 \\
2 \\
1\end{array}$ & $\begin{array}{l}2 \\
0 \\
0\end{array}$ & $\begin{array}{l}3 \\
6 \\
14\end{array}$ \\
\hline
\end{tabular}

Ps. aeruginosa in their stools. This acquisition rate is higher than in the patients treated with other antibiotics and significantly different from those who received no antibiotics (Fisher exact probability test, $\mathrm{P}=0.004$ ). A less marked trend was seen with proteus $(P=0.08)$.

Of the seven patients acquiring pseudomonas four who were being fed from the hospital diet kitchen acquired the same strain (serotype 6, phage type (119x)), which was known to be present in the diet kitchen at this time. One patient not

\section{(A)}

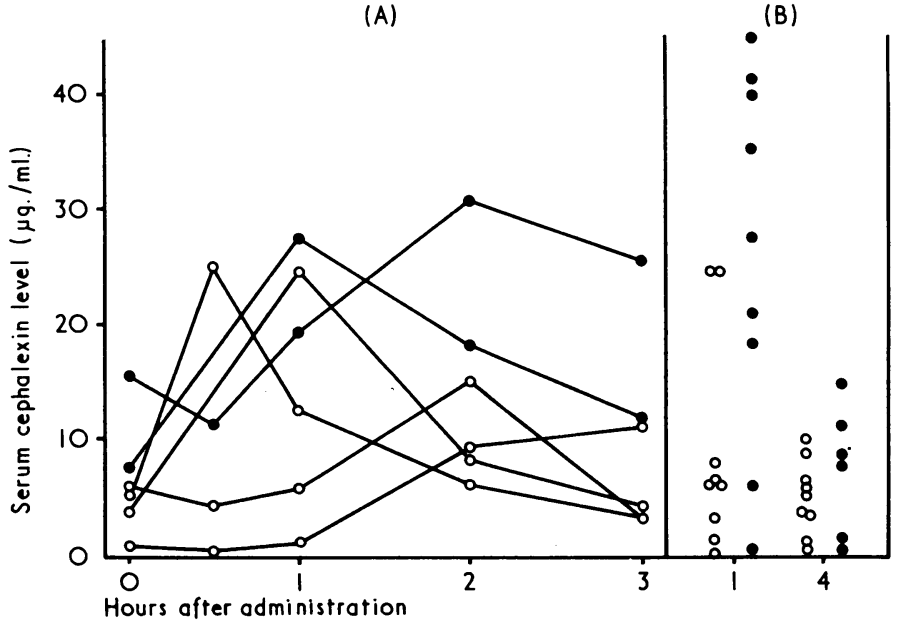

FIG. 1 ( $A$ and B).-Serum levels following administration of cephalexin $(0,0.5$ g.; 9,1 g.). 
only showed gut colonization with this strain but subsequently developed a urinary superinfection with it.

The change in haemoglobin level during cephalexin treatment was $-0.3 \pm 0.5 \mathrm{~g} . / 100 \mathrm{ml}$. (mean \pm S.E., 12 patients). No change was found in the other laboratory tests.

\section{Discussion}

Urinary recovery of cephalexin ranged from 29 to $89 \%$ of the daily ingested dose, which is significantly less than that found in healthy volunteers by other workers (Kind et al., 1968; Gower and Dash, 1969). Peak blood levels occurred at half-hour to two hours (Fig. $1 \mathrm{~A}$ ), and the variable rate of absorption is illustrated by the variation in the one-hour blood levels (Fig. 1 B).

Gower and Dash (1969) suggested that, because of almost complete absorption of cephalexin from the gastrointestinal tract, alteration of bowel flora would be minimal. A significant number of our patients, however, acquired either pseudomonas or proteus in their stools (Table II), which confirms the view (Shooter et al., 1966) that antibiotic therapy may be associated with increased faecal carriage of $P s$. aeruginosa.

Our results indicate that ingested organisms may replace or displace organisms in the lower gastrointestinal tract. Hötzel and Barnes (1966) suggested that large-bowel flora is determined in the upper alimentary tract, and that this process is influenced by antibiotic therapy. It has been found that large oral doses of pseudomonas are necessary $\left(10^{4}-10^{5}\right.$ organisms $)$ before it can be detected in the faeces but that colonization is aided by ampicillin (Buck and Cooke, 1969). Cephalexin may have a similar and more pronounced effect than ampicillin. This would explain the higher carriage rate of pseudomonas in cephalexin-treated patients compared with those not on antibiotic treatment.

Previous reports suggest that patients may become colonized with Ps. aeruginosa ingested in food (Shooter et al.,
1969) and that the patient's own gastrointestinal tract may be a source of infection with this organism (Shooter et al., 1966, 1969). We found that four patients became colonized with the same ingested strain (serotype 6, phage type (119x)) and that one patient subsequently developed a urinary infection with this strain. This confirms that food may be a source of infection in hospital. It must be stressed, however, that this may apply only to the present population, who were known to be ingesting repeated doses of pseudomonas. Individuals living at home are probably not exposed to colonization by pseudomonas to the same extent (Buck and Cooke, 1969). Acquisition of proteus may have the same basis.

Cephalexin eliminated the infecting organism in $75 \%$ of this small series of patients, and the high urinary concentrations obtained $(920-4,700 \mu \mathrm{g} . / \mathrm{ml}$. $)$ make this an efficient urinary antiseptic. The peak blood levels may also produce a systemic effect.

The pronounced fall in haemoglobin levels found by Meyers et al. (1969) has not been confirmed.

Drs. K. O. Black and A. M. Dawson kindly allowed us to study patients under their care, and we are grateful to Professors R. A. Shooter and F. W. O'Grady for helpful advice. Cephalexin assays were performed by Mr. R. Ryden of Eli Lilly and Co. Ltd., who supplied cephalexin.

REFERENCES

Buck, A. C., and Cooke, E. M. (1969). Fournal of Medical Microbiology, 2, 521

Gower, P. E., and Dash, C. H. (1969). British fournal of Pharmacology, 37, 738

Hötzel, D., and Barnes, R. H. (1966). Vitamins and Hormones, 24, 115.

Kind, A. C., Kestle, D. G., Standiford, H. C., and Kirby, W. M. M. (1968)

Antimicrobial Agents and Chemotherapy, p. 361 .
Levison, M. E., Johnson, W. D., Thornhill, T. S., and Kaye, D. (1969). fournal of the American Medical Association, 209, 1331.

Meyers, B. R., Kaplan, K., and Weinstein, L. (1969). Clinical Pharmacology and Theraptutics, 10, 810 .

Seftel, H. C., Robinson, R. G., Kew, M. C., and Goldin, A. R. (1969) Medical Proceedings, 15, 335 .

Shooter, R. A., et al. (1966). Lancet, 2, 1331.

Shooter, R. A., et al. (1969). Lancet, 1, 1227.

\section{Preliminary Communication}

\section{Reduction of Reaction due to Iron Dextran Infusion using Chloroquine}

British Medical Fournal, 1970, 3, 625-627

\begin{abstract}
Cummary: The use of promethazine and chloroquine sulphate to reduce reaction to total dose infusion of iron dextran (Imferon) is described. The patients chosen for the investigation were anaemic pregnant African women living in the coastal region of East Africa where malaria due to Plasmodium falciparum is holoendemic. The results show that promethazine has little value in the reduction of reactions whereas chloroquine appears to be effective.
\end{abstract}

\section{INTRODUCTION}

The treatment of iron-deficiency anaemia with total dose infusion of iron dextran (Imferon) has been reported in all parts of the world. The main advantage of single-dose parenteral iron therapy is that large number of patients can be treated in areas with few hospital beds. The main disadvantage is the incidence of generalized reaction in pregnancy. In tropical areas where malaria is endemic the additional load of iron dextran on the lymphoreticular system may disturb the altered cell-mediated immune mechanisms of pregnancy. This may precipitate clinical malaria.
This paper compares promethazine, an antihistamine, with chloroquine in the reduction of reactions to total dose iron dextran infusion in a region where Plasmodium falciparum is holoendemic.

\section{Patients and Treatment}

Dar-es-Salaam, Tanzania, is in the coastal region of East Africa. Here anaemia in pregnant African women presents a major problem in management. About $10 \%$ of these women have haemoglobin levels under $50 \%(7.4 \mathrm{~g} . / 100 \mathrm{ml}$.). This gives a minimum of 1,500 patients in need of intensive therapy each year.

An investigation of response to iron dextran therapy by total dose infusion was planned. All women with (1) pregnancies of less than 36 weeks having haemoglobin levels of $50 \%$ or less, and (2) those with pregnancies estimated to be 36 weeks or more with haemoglobin levels of $60 \%$ or less were admitted to hospital for investigation and treatment.

Total dose infusion of iron dextran was given to 1,000 patients, 928 pregnant and 72 in the puerperium. They were divided into four equal groups (A, B, C, and D) for the comparison of reaction to total dose infusion. The treatment given in each group is shown in Table $I$.

The estimated dose of iron dextran was calculated from the manufacturer's suggested formula: milligrams of elemental iron required $=0.66 \mathrm{WD}$, where $\mathrm{W}=$ body weight in kilograms and $\mathrm{D}=\%$ haemoglobin deficit. The infusion was started at 20 drops per minute for 30 minutes and if no reaction 